\title{
FOREIGN BODY IN THE NOSE SIMULATING ACUTE DACRYOCYSTITIS*
}

\author{
BY \\ J: GIBSON MOORE \\ London
}

FOREIGN bodies in the nose are well known in ear, nose, and throat clinics; they are more common in children in whom they are usually self-introduced.

In this case it would appear that a man aged 71 years tolerated a foreign body two inches long for 10 years until it caused a discharging sinus below the right eye and he was forced to obtain medical advice.

\section{Case Report}

The patient first attended on July 17, 1953, when he gave history of a fall on his face about a month previously, since when he had noticed a discharge below the right eye. There was no history which might lead to suspicion of a nasal disorder and it was only on questioning at a later date that he said that the right nostril had been blocked for many years. On examination he had a sinus below the right inner canthus and the appearance was quite typical of an acute lacrimal abscess which had recently burst. He was given intramuscular injections of penicillin 300,000 units twice daily for 4 days and the condition settled satisfactorily.

He attended again October 22, 1953, with a recurrence, and, as there was no reason to suppose that this was not an acute dacryocystitis, it was decided to remove the sac. At operation, when the sac had been removed and the lacrimal fossa was bared, it was noted that there was a small hole in the lacrimal bone exuding pus and presumably communicating with the nose. It was only then seen that the trouble was due to some nasal abnormality.

The presence of a large foreign body was revealed by $x$ ray (Figs 1 and 2) and this was later removed by Dr. Arciszewski.

The foreign body (Fig. 3) was clearly a catheter spigot and the incrustations seen beside it in the photograph give some indication of the prolonged period of impaction. It was, of course, interesting to try to discover how it could have entered the nostril apparently unknown to the patient. He did not appear to be a psychiatric case who might have placed it there himself for some reason, but he had extremely capacious nostrils and it was easy to see that the spigot had a very roomy resting place. He volunteered the suggestion that it had been placed there by the Nazis before the War when he was persecuted for his religious beliefs, but this seems an unlikely explanation. He had had investigations in two different London hospitals in 1942: the first for the possibility of gastric ulcer and the second for cystitis. It is just conceivable that a Ryles tube might have been closed by a spigot and that the tube might have slipped down pulling the spigot up the nose. He might even had done this himself when half asleep. It is more difficult to conjecture how a spigot used for bladder catherization could have entered the nose but these were the only relevant incidents that he could give. 


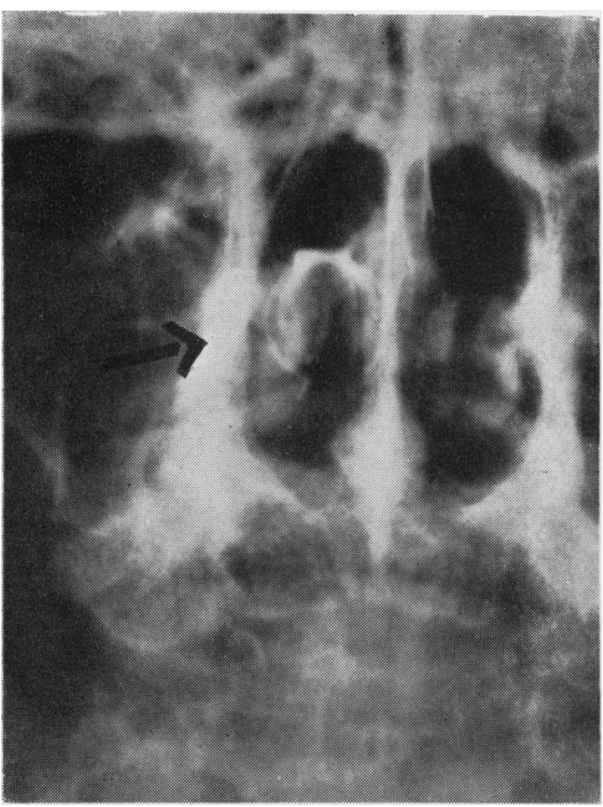

FIG. 1.-Catheter spigot impacted in the nose.

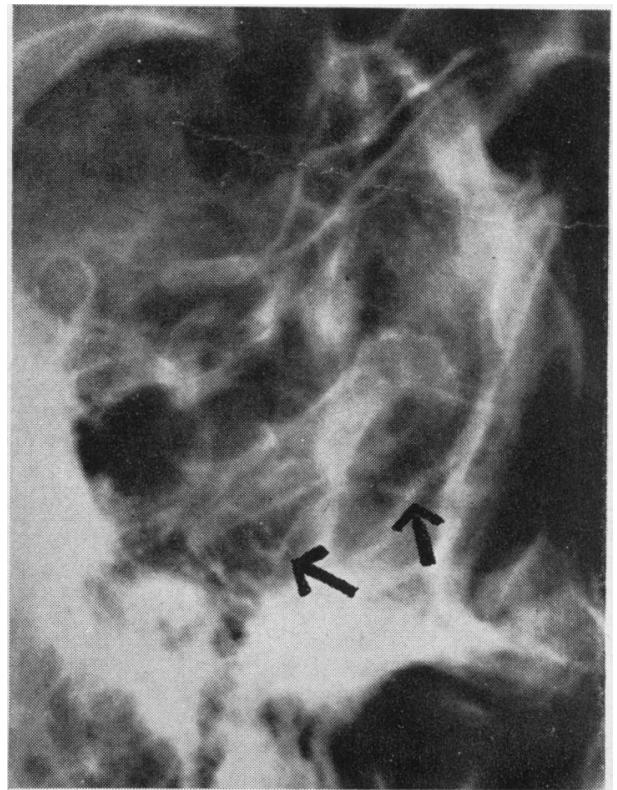

Fig. 2.-Lateral view of Fig. 1.

\section{Discussion}

It is easy to be wise after the event, and undoubtedly an earlier $x$-ray and reference to one's E.N.T. colleagues would have saved this patient some discomfort and perhaps a dry eye, although the latter is doubtful as, at operation,
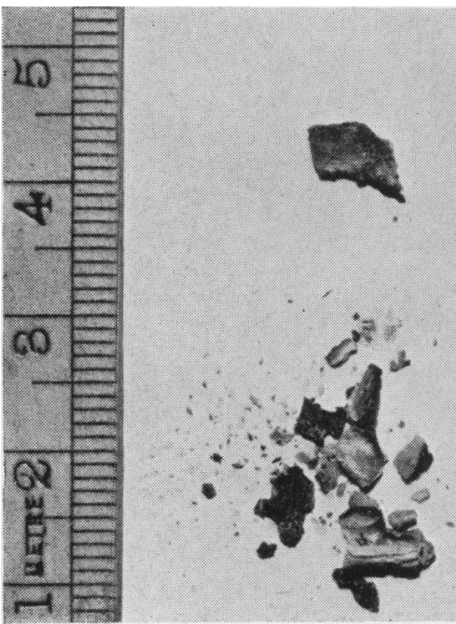

FIG. 3.-Spigot after removal. Note incrustations corroborating the 10-year history of impaction. the lacrimal sac appeared to be largely destroyed. The question of routine E.N.T. examination is of doubtful value in cases of chronic or acute dacryocystitis. In the case of the former condition, such an authority as Traquair (1941), considering operation for epiphora, states that in no case (out of 548) was a preliminary rhinological examination taken, and that nothing was found during operation or later to indicate that the treatment would have required 
modification or that the results would have been different had such an examination been made. Presumably this will also be true for the acute dacryocystitis, which normally follows the chronic stage. There is always the possibility of an extension from an infected ethmoid or frontal sinus causing confusion, but here the maximum swelling is usually above the internal palpebral ligament while in the case quoted above the fistula was in the "classical" position below it.

\section{Summary}

A case history is presented of a foreign body $2^{\prime \prime}$ long in the nose which seems to have been present for 10 years and caused erosion of the lacrimal fossa simulating an acute dacryocystitis.

My thanks are due to Dr. Arciszewski, registrar, to Mr. J. N. Deacon of Edgware General Hospital, and to Miss Shaw who took the photographs.

\section{REFERENCE}

Traquair, H. M. (1941). Arch. Ophthal. (Chicago), 26, 165. 